\title{
Genetic diversity and structure of Capsicum annuum as revealed by start codon targeted and directed amplified minisatellite DNA markers
}

\author{
David O. Igwe $e^{1,2,3^{*}}$ (D) Celestine A. Afiukwa ${ }^{1,2}$, George Acquaah ${ }^{3}$ and George N. Ude ${ }^{3}$
}

\begin{abstract}
Background: Identification of high resolving DNA-based markers is of paramount importance to unlock the potential of genetic diversity and selection of unique accessions of Capsicum annuum L., within Cross River and Ebonyi States of Nigeria, for breeding and conservation. Therefore, we comparatively explored the effectiveness of start codon targeted (SCOT) and directed amplified minisatellite DNA (DAMD) markers for diversity analysis of the accessions. Fifteen accessions were collected for DNA extraction and amplifications with the markers.

Results: Dendrograms from SCOT and DAMD categorized the accessions into five and three genetic groups, respectively, while the principal component analysis identified five genetic clusters, each from the markers. The average values of allele, gene diversity and polymorphic information content detected with SCOT and DAMD demonstrate that the two markers were effective and efficient, especially, SCOT in genetic diversity study of the accessions of pepper. Number of polymorphic loci (NPL) and percentage polymorphic loci (PPL) from SCOT (NPL = 64, $\mathrm{PPL}=80.00-95.73 \%)$ and $\mathrm{DAMD}(\mathrm{NPL}=56, \mathrm{PPL}=53.33-86.67 \%)$ were high, but higher in SCoT markers. Other effective genetic parameters (effective number of alleles, Nei's genetic diversity and Shannon's information indices) identified with the two marker systems elucidated the allelic richness, rich genetic diversity within the populations and informative nature of the markers, especially SCOT. The intraspecific genetic diversity, interspecific genetic diversity, and coefficient of differentiation obtained with SCOT and DAMD further exposed the genetic structure with more genetic divergence within than among the populations of the accessions. Estimate of gene flow from the SCOT markers was 3.8375 and 0.6 .2042 for the DAMD markers. The estimate of gene flow values from the markers indicated extensiveness with SCOT $(N m=3.8375)$ and extremely extensive with DAMD $(N m=6.2042)$ among the populations.

Conclusion: This study shows that SCOT markers may be more useful and informative than DAMD in measuring genetic diversity and differentiation of the accessions of the genus Capsicum. Genetic parameters obtained with SCOT showed that the accessions from Cross River were more genetically diverse than the ones from Ebonyi State. Therefore, SCOT may be a preferred marker in evaluating genetic diversity for improvement and conservation of this spicy crop, C. capsicum.
\end{abstract}

Keywords: Cetyltrimethylammonium bromide, Germplasm, Shannon's information index, Percentage polymorphic loci, Nei's genetic diversity, Estimate of gene flow, Capsicum annuum

\footnotetext{
* Correspondence: digwe@bowiestate.edu

'Department of Biotechnology, Faculty of Science, Ebonyi State University,

Abakaliki 053, Nigeria

Biotechnology and Research Development Centre, Ebonyi State University,

Abakaliki, Ebonyi State 053, Nigeria

Full list of author information is available at the end of the article
}

(c) The Author(s). 2019 Open Access This article is distributed under the terms of the Creative Commons Attribution 4.0 International License (http://creativecommons.org/licenses/by/4.0/), which permits unrestricted use, distribution, and

reproduction in any medium, provided you give appropriate credit to the original author(s) and the source, provide a link to the Creative Commons license, and indicate if changes were made. The Creative Commons Public Domain Dedication waiver (http://creativecommons.org/publicdomain/zero/1.0/) applies to the data made available in this article, unless otherwise stated. 


\section{Background}

Pepper (Capsicum spp.), belonging to family Solanaceae and sub-family Solanoideae is grown worldwide for its vital uses as vegetables, spices, ornaments, medicines, lachrymatories, vitamins $\mathrm{A}$ and $\mathrm{C}$ [1-7]. It was discovered as early as 6000 years ago and it is regarded as the first spice utilized by human beings [3, 8]. The ancestral sources are Central and Southern America hinged in Bolivia, while Brazil is the center for genetic diversity of this important spice [9-12]. Thirty-eight species of Capsicum have been reported out of which Capsicum annuum L., C. frutescens L., C. Chinense Jacq., C. baccatum L. (aji), and C. pubescens Ruiz and Pay were considered to have been domesticated and maintained through more than five independent occurrences $[9,13,14]$. Some of these species were considered to have undergone a process of an independent domestication in at least two zones of the New World including Mesoamerica (C. annum and C. frutescens) and South America (C. chinese, C. baccatum and C. pubescens) $[9,15]$. The cultivated species (C. annuum, C. frutenscens, C. chinese, C. pubescens and C. baccatum var. pendulum) are of great economic importance and they possess good attributes that can be maintained through domestication $[8,16,17]$. However, continuous selection during domestication brought about emergence of novel lines with phenotypic traits including larger, non-pungent fruit with greater shape variation and tremendous increases in fruit mass $[18,19]$. Breeding programs targeting crop improvement are accelerated by the availability of well-characterized genetically diverse germplasm of pepper accessions and this is obtainable through the application of informative molecular markers to complement the roles of a morphologybased identification process.

Many marker systems of different categories including amplified fragment length polymorphisms (AFLP), simple sequence repeat (SSR), random amplified polymorphic DNA (RAPD), isozymes, inter-simple sequence repeat (ISSR), restriction fragment length polymorphism (RFLP), gene-based markers of start codon targeted and expressed sequence tag-simple sequence repeat (SCoT and ESTSSR), and single nucleotide polymorphism (SNP) have been utilized in studying and characterizing genetic loci linked to diversity, relationships, variations, parental selection, cultivar identity, phenotypic traits, purity, population studies, and resistance to diseases in Capsicum species [20-42]. The basic information derivable from genetic variability of these potential markers could provide useful information that will assist plant breeders to manage and improve germplasm [23]. Use of microsatellite markers that are polymorphic, multi-allelic, reproducible and widely distributed in the pepper accessions could facilitate the selection of traits of interest and potential breeding materials for introgression through molecular marker-assisted breeding and germplasm conservation [23, 43, 44]. Functional gene-based marker such as SCoT, has been applied in other crops (Elymus sibiricus) [45]; (Boehmeria nivea L. Gaudich) [46]; and (Vigna unguiculata L.) [22]. Also another potential marker, directed amplified minisatellite DNA (DAMD), has also been useful in other crops including Flavoparmelia caperata [5]; Musa acuminata colla [47]; and Citrus [48].

Start codon targeted markers that are derivable from transcribed regions of the genome can be potentially useful for various applications in plant genotyping since they are capable of exposing polymorphisms that might be directly related to gene functions. These molecular markers were initially described, based on the observation that the short conserved regions of plant genes are surrounded by the ATG translation start codon $[49,50]$. The utility of SCoT was advocated due to their inherent features such as reproducibility, possibility of getting codominance during amplification, accuracy in investigation of genetic relatedness and genetic diversity of plants [50-54]. Also, DAMD markers, believed to be tandemly repeated units of genomes are satellite marker systems that have become valuable and of great importance in identification of genotypes following discovery [55]. They exhibit many variations as inversional mutations that result in their orientation and distribution on both strands of the DNA sequences $[56,57]$. Till now, SCoT and DAMD marker techniques have not been comparatively applied in the assessment of genetic diversity of pepper. Therefore, the objective of this study is to compare the efficacies of SCOT and DAMD markers in assessing genetic diversity among the accessions of $C$. annum from Cross River and Ebonyi States of Nigeria.

\section{Methods}

\section{Plant materials}

Fifteen accessions of $C$. annuum were collected from Cross River and Ebonyi States of Nigeria (Additional file 1: Table S1). One accession was purposefully obtained from each of the fifteen locations across Local Government Areas (LGAs) in Cross River and Ebonyi States to assess the efficiency of the two DNA-based molecular markers in studying the genetic diversity of $C$. annuum.

\section{DNA extraction}

DNA extraction of the accessions was carried out using a modified Cetyltrimethylammonium bromide (CTAB) method [58]. Briefly, a young leaf of C. annuum was collected and weighed between 100 and $200 \mathrm{mg}$. It was thoroughly ground with $500 \mu \mathrm{L}$ of the extraction buffer (EB: 2\% CTAB, $100 \mathrm{mM}$ Tris- $\mathrm{HCl}, 20 \mathrm{mM}$ EDTA, $1.4 \mathrm{M}$ $\mathrm{NaCl}$ and $0.2 \% \beta$-mercaptoethanol) and later made up with additional $200 \mu \mathrm{L}$ of the EB before transferring to a sterile $1.5 \mathrm{ml}$ microcentrifuge tube for homogenous mixture. It was incubated at $65^{\circ} \mathrm{C}$ for $15 \mathrm{~min}$ followed by 
addition of equal volume of phenol, chloroform and isoamyl alcohol in the ratio of 25:24:1. It was mixed and centrifuged at 14,000 rpm (rpm) for $15 \mathrm{~min}$ after which $500 \mu \mathrm{L}$ of the supernatant was transferred to a new sterile $1.5 \mathrm{ml}$ microcentrifuge tube. It was precipitated by adding $400 \mu \mathrm{L}$ of cold-isopropanol, followed by gentle inversion prior to incubation at $-20^{\circ} \mathrm{C}$ for overnight. It was centrifuged at $12,000 \mathrm{rpm}$ to sediment the DNA prior to washing with $600 \mu \mathrm{L}$ of $70 \%$ ethanol. It was subsequently air-dried and eluted with $100 \mu \mathrm{L}$ of sterile water for polymerase chain reaction (PCR) set up.

\section{Polymerase chain reaction and agarose gel electrophoresis}

A total of 10 SCoT [47] and 10 [59] DAMD primers were used in this study. Polymerase chain reaction amplification was performed in volume of $25 \mu \mathrm{L}$ consisting of $2.0 \mu \mathrm{L} 100 \mathrm{ng}$ DNA, $2.5 \mu \mathrm{L}$ of $10 \times$ Buffer (Bioline), $1.5 \mu \mathrm{L}$ of $50 \mathrm{mM} \mathrm{MgCl}$ (Bioline), $2.0 \mu \mathrm{L}$ of $2.5 \mathrm{mM}$ dNTPs (Bioline), and $0.2 \mu \mathrm{L} 500 \mathrm{U}$ Taq DNA polymerase (Bioline), $1.0 \mu \mathrm{L}$ of $10 \mu \mathrm{M}$ each of the SCoT and DAMD primers (Additional file 2: Table S2) and $15.80 \mu \mathrm{L}$ of $500 \mathrm{ml}$ diethylpyrocarbonate (DEPC)-treated water (Invitrogen Corporation, USA). The PCR cycling profile used for the reaction consisted of an initial step at $95^{\circ} \mathrm{C}$ for 5 min., 40 cycles of $94{ }^{\circ} \mathrm{C}$ for 30 s, $55-65^{\circ} \mathrm{C}$ for $35 \mathrm{~s}, 72^{\circ} \mathrm{C}$ for $1 \mathrm{~min}$, and a 10 -min final extension at $72^{\circ} \mathrm{C}$. Eight (8) $\mu \mathrm{L}$ of the PCR products were electrophoresed in a $1.5 \%$ agarose gel containing $0.5 \mathrm{mg} / \mathrm{ml}$ ethidium bromide and photographed on Transilluminator UV light (Fotodyne Incorporated, Analyst Express, USA).

\section{Data analysis}

Data matrix of SCoT and DAMD marker profiles for fragments of similar molecular weights from each amplicon or individual were scored as 1 (presence of alleles) and 0 (absence of alleles). The data achieved from the scoring of reproducible bands from SCoT and DAMD amplicons after the second repeated experiments were used for dendrogram reconstruction using Unweighted Pair Group Method with Arithmetic Mean (UPGMA) and dissimilarity index in Jaccard's option [60]. The analysis was conducted using Numerical Taxonomy and Multivariate Analysis System (NTSYSpc) software version 2.02. Furthermore, the genetic diversity, allele frequency and polymorphic information content (PIC) were computed using PowerMarker (Version 3.25). DARwin version 5 was used for principal component analysis (PCA), while effective number of alleles $(\mathrm{Ne})$, Nei's genetic diversity $(H)$, and Shannon's information index (I) [61] and population structure analyses including total genetic diversity (intraspecific diversity, $\mathrm{Ht}$ ), gene diversity within the population (interspecific diversity, $\mathrm{Hs})$, coefficient of differentiation $\left(\mathrm{G}_{\mathrm{ST}}\right)$ and estimate of gene flow $(\mathrm{Nm})$ of the accessions were done using POPGENE software version 1.32.

\section{Results \\ Genetic diversity of accessions of Capsicum annuum as identified by start codon targeted markers}

To discern the level of genetic diversity in 15 accessions of $C$. annuum studied, a total of 10 SCoT primers were used for the study. Out of the 10 primers used, five (5) of them produced reproducible bands that were used in the analyses as exemplified in the gel images of SCoT13 and SCoT20 markers (Figs. 1 and 2). A dendrogram of the 15 accessions using UPGMA procedure clustered the accessions into five major groups at a genetic distance threshold of 0.666 (Fig. 3). Group I was subdivided into subgroups I and II denoted as SGI and SGII, respectively. The SGI clustered $\mathrm{CrPe}-1$, while SGII had CrPe-3, CrPe-5, CrPe-6, EbPe-5, CrPe-8 and EbPe-7. The accession EbPe-7 was the most genetically isolated one in the group followed by $\mathrm{CrPe}-8$. The accession (CrPe) in SGI was collected from Cross River, while those in SGII were from both Cross River and Ebonyi (EbPe) States. Group II had CrPe-7, EbPe-6 and EbPe-3 and they were from Cross River and Ebonyi States. Group III clustered together accessions EbPe-1 and EbPe-2 from Ebonyi. Group IV had only CrPe-2 accession that was collected from Cross River State. Group VI contained $\mathrm{CrPe}-4$ and EbPe-4 accessions that were collected from Cross River and Ebonyi States, respectively. Principal component analysis of the generated amplicons resulted into five clusters (Additional file 3: Fig. 1). The clustering of each is a representative of unique accession or accessions of $C$. annuum.

The five SCoT markers amplified a total of 57 alleles (Table 1). The amplified alleles from each primer ranged from 7 to 14, with a mean of 12.000 . Polymorphic information content values ranged from $0.7735-0.9193$, with a mean value of 0.8709 . The SCoT markers including SCoT13, SCoT28, SCoT20, SCoT24 and SCoT16 were found to be polymorphic. The genetic diversity ranged from $0.7911-0.9244$, with a mean of 0.8815 , while major allele frequency spanned from 0.1333-0.4000, with a mean of 0.2000 . The identified allelic counts and frequencies from each of the SCoT loci ranged from 1 to 6 and $0.0667-0.4000$, respectively (Additional file 4 : Table S3).

The genetic diversity in $\mathrm{CrPe}-2$ was identified to be highest among the accessions, with effective number of alleles $(\mathrm{Ne})$, Nei's genetic diversity $(\mathrm{H})$, and Shannon's information index (I) values of 1.9996, 0.4999 and 0.6931, respectively (Table 2). On the other hand, the genetic diversity in $\mathrm{CrPe}-4$ was the lowest, with $\mathrm{Ne}, \mathrm{H}$, and I values of $1.0270,0.0263$ and 0.0708 , respectively. The genetic diversity indices of these accessions were ranked in an ascending order as $\mathrm{CrPe}-2>(\mathrm{CrPe}-8$, EbPe- 


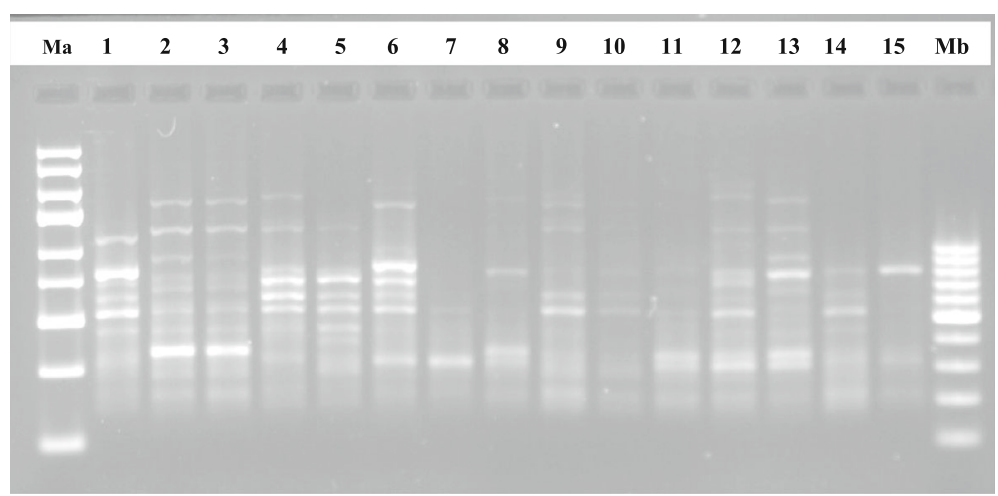

Fig. 1 Fifteen Capsicum annuum DNA samples amplified with SCoT13 marker. Ma = 1 kb DNA ladder; Mb = 100 bp DNA ladder; 1-8=C. annuum accessions from different locations of Cross River State, Nigeria; and 9-15=C. annuum accessions from different locations of Ebonyi State, Nigeria

1) $>\mathrm{CrPe}-6>\mathrm{CrPe}-3>(\mathrm{CrPe}-5, \mathrm{EbPe}-5)>\mathrm{CrPe}-7>\mathrm{CrPe}-$ $1>(\mathrm{EbPe}-2, \mathrm{EbPe}-3)>\mathrm{EbPe}-4>\mathrm{CrPe}-4$. Effective number of alleles, $\mathrm{H}$ and $\mathrm{I}$ values spanned from $1.4149 \pm$ $0.2594-1.8026 \pm 0.3338, \quad 0.2702 \pm 1379-0.4160 \pm 0.1701$ and $0.4218 \pm 0.1962-0.5831 \pm 0.2376$, respectively. The mean values of $\mathrm{Ne}, \mathrm{H}$ and I obtained from the accessions collected within Cross River State were 1.7373, 0.4011 and 0.5747, respectively, while those from Ebonyi had $1.6568,0.3850$ and 0.5685 , respectively. The overall mean values of $\mathrm{Ne}, \mathrm{H}$ and I detected in the accessions from the two States using SCoT were 1.6971, 0.5936 and 0.8590 , respectively.

The genetic variation in pepper accessions from Cross River assessed using SCoT markers, revealed that the mean values of total gene diversity $(\mathrm{Ht})$, gene diversity within population $(\mathrm{Hs})$, coefficient of gene differentiation $\left(\mathrm{G}_{\mathrm{ST}}\right)$ and level of gene flow $(\mathrm{Nm})$ were $0.4011,0.3729$, 0.0685 and 9.2368, respectively (Table 3 ). Values of $\mathrm{Ht}$, $\mathrm{Hs}, \mathrm{G}_{\mathrm{ST}}$ and $\mathrm{Nm}$ recorded in the accessions from Ebonyi were $0.3850,0.3200,0.1918$ and 2.8444 , respectively. The overall values of $\mathrm{Ht}, \mathrm{Hs}, \mathrm{G}_{\mathrm{ST}}$ and $\mathrm{Nm}$ obtained from the entire populations were $0.3936,0.3482,0.1152$ and 3.8375 , respectively. The $\mathrm{G}_{\mathrm{ST}}$ value recorded 0.1153 indicating about $12 \%$ of the total genetic divergence among the populations and the remaining $88 \%$ within the populations. Across the SCoT markers, the numbers of polymorphic loci (NPL) and percentage polymorphic loci (PPL) were $12-13$ and $80.00-95.73 \%$, respectively (Additional file 5: Table S4). Effective number of alleles, $\mathrm{H}$ and I values obtained were $1.4149 \pm 0.2594-1.8026 \pm$ $0.3338, \quad 0.1702 \pm 0.1379-0.4160 \pm 0.1701$ and $0.4218 \pm$ $0.1962-0.5831 \pm 0.2376$, respectively.

\section{Genetic diversity of accessions of Capsicum annuum as identified by directed amplified minisatellite DNA markers}

To ascertain the level of genetic diversity in 15 accessions of C. annuum, a total of 10 DAMD primers were used for the accessions. Out of the 10 primers used, five (5) reproducible primers obtained were used in the analyses as demonstrated in the gel images of DAMD25 and DAMD16 primers (Figs. 4 and 5). A dendrogram of the

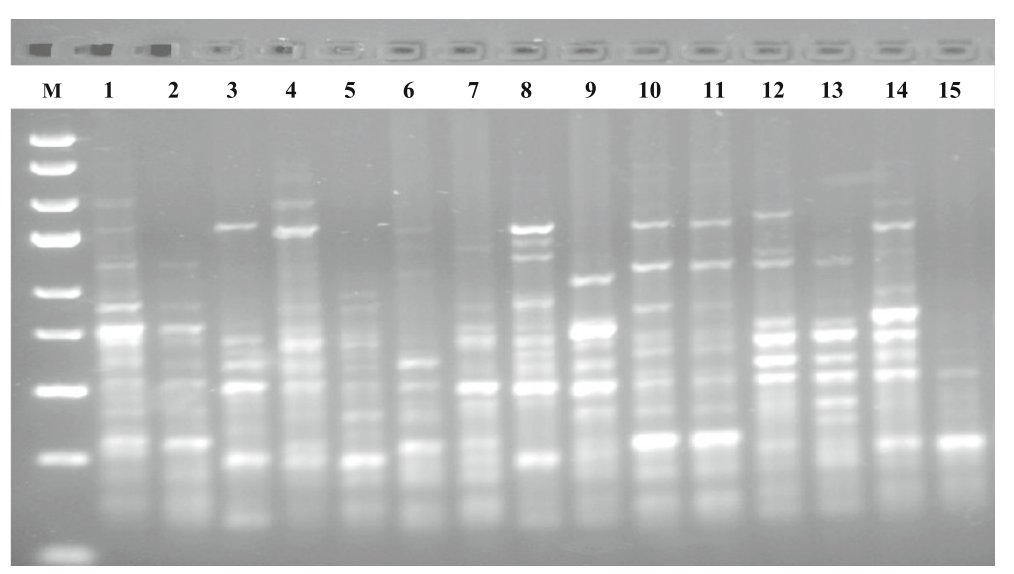

Fig. 2 Fifteen Capsicum annuum DNA samples amplified with SCOT20 marker. $M=1$ kb DNA ladder; $1-8=C$. annuum accessions from different locations of Cross River State, Nigeria; and 9-15 = C. annuum accessions from different locations of Ebonyi State, Nigeria 


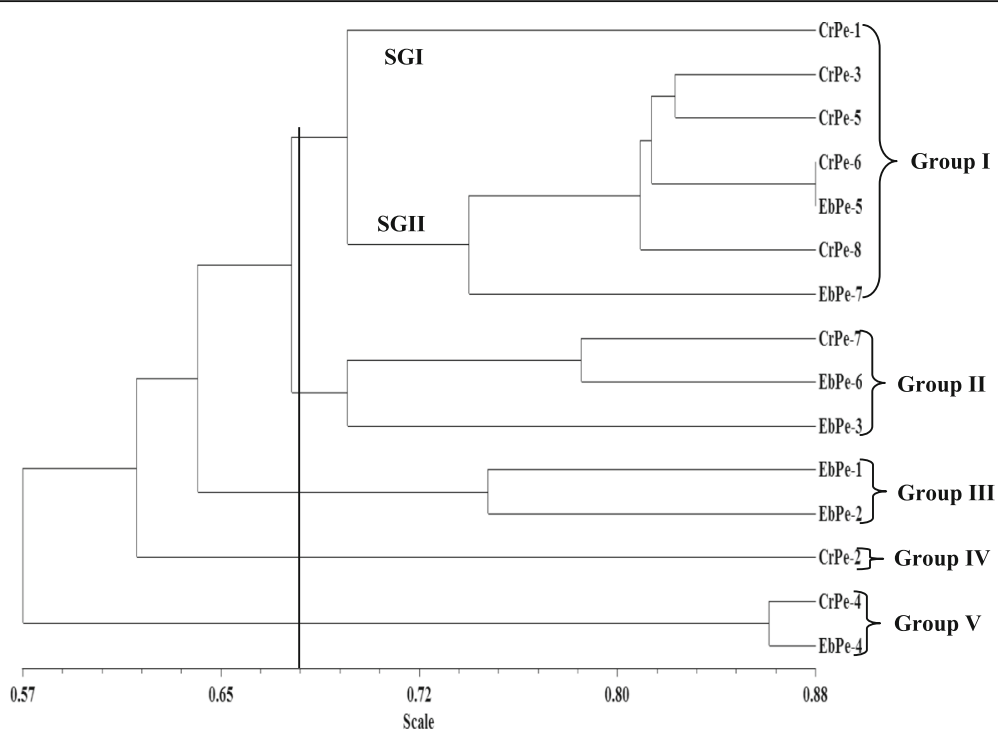

Fig. 3 Dendrogram of 15 accessions of Capsicum annuum amplified with start codon targeted markers

15 accessions using UPGMA procedure clustered them into three major groups at a genetic distance threshold of 0.6400 (Fig. 6). Group I was subdivided into subgroups I and II denoted as SGI and SGII, respectively. The SGI consisted of EbPe-1 and EbPe-5 accessions from Ebonyi State, while SGII was further subdivided into a (EbPe-3, CrPe-6, CrPe-8 and $\mathrm{CrPe}-4), \mathrm{b}$ (EbPe-4, CrPe-5 and EbPe-7) and c (CrPe- 1 and $\mathrm{CrPe}-3)$. Group II had EbPe-6 and $\mathrm{CrPe}-2$, while group III clustered accessions EbPe-2 and $\mathrm{CrPe}-7$. Principal component analysis of yielded five clusters (Additional file 6: Fig. 2). Each cluster contained an accession or accessions of $C$. annuum based on their dissimilarity indices within their respective coordinates.

The five DAMD primers amplified a total of 46 alleles (Table 4). The amplified alleles from each DAMD ranged from 6 to 11, with a mean value of 10.1667. Polymorphic information content values ranged from 0.6519-0.8887 with an average of 0.8268 . The DAMD primers including DAMD17R, DAMD13, DAMD16, DAMD1F and DAMD25 were polymorphic. The genetic diversity ranged from $0.6933-0.8978$ with a mean value of 0.8430 , while

Table 1 Allele frequency, number of alleles, genetic diversity and polymorphic information content of start codon targeted

\begin{tabular}{lllll}
\hline Marker & Major allele frequency & No of Allele & Gene diversity & PIC \\
\hline SCoT13 & 0.1333 & 14.0000 & 0.9244 & 0.9193 \\
SCoT28 & 0.1333 & 13.0000 & 0.9156 & 0.9093 \\
SCoT20 & 0.1333 & 14.0000 & 0.9244 & 0.9193 \\
SCoT24 & 0.3333 & 7.0000 & 0.8000 & 0.7746 \\
SCoT16 & 0.4000 & 9.0000 & 0.7911 & 0.7735 \\
Mean & 0.2000 & 12.0000 & 0.8815 & 0.8709 \\
\hline
\end{tabular}

PIC Polymorphic information content the major allele frequency spanned between 0.1333 and 0.4667 , with a mean of 0.2556 . Detected allelic counts and frequencies from each of the DAMD loci were respectively 1-7 and 0.0667-0.4667 (Additional file 7: Table S5). The genetic diversity in EbPe-2 was the highest, with $\mathrm{Ne}, \mathrm{H}$, and I values of 1.9501, 0.4872 and 0.6803 , respectively (Table 5). Contrarily, the genetic diversity in EbPe-4 was the lowest, with $\mathrm{Ne}, \mathrm{H}$, and I values of 1.0000, 0.0000 and 0.0000 , respectively. The genetic diversity values of these accessions were ranked as EbPe- $2>\mathrm{EbPe}-6>\mathrm{CrPe}-7>$ $\mathrm{CrPe}-2>(\mathrm{CrPe}-1, \quad$ EbPe- 3$)>\mathrm{EbPe}-1>\mathrm{CrPe}-3>\mathrm{EbPe}-$ $5>(\mathrm{CrPe}-6, \mathrm{CrPe}-8)>\mathrm{EbPe}-7$ from high to low. The mean values of $\mathrm{Ne}, \mathrm{H}$ and I obtained from the accessions collected within Cross River State were 1.4015, 0.2693 and 0.4333, respectively, while those from Ebonyi had 1.4520, 0.2776 and 0.4265 , respectively. The overall mean values of $\mathrm{Ne}, \mathrm{H}$ and I detected in the accessions from the two States using DAMD were respectively 1.4268, 0.4081 and 0.6466 .

The genetic variation in pepper accessions from Cross River, assessed using DAMD markers revealed that the mean values of $\mathrm{Ht}, \mathrm{Hs}, \mathrm{G}_{\mathrm{ST}}$ and $\mathrm{Nm}$ were 0.2693 , $0.2465,0.0992$ and 6.4983, respectively (Table 6). Values of $\mathrm{Ht}, \mathrm{Hs}, \mathrm{G}_{\mathrm{ST}}$ and $\mathrm{Nm}$ recorded in the accessions from Ebonyi were 0.2776, 0.2600, 0.0551 and 17.9512, respectively. The overall values of $\mathrm{Ht}, \mathrm{Hs}, \mathrm{G}_{\mathrm{ST}}$ and $\mathrm{Nm}$ identified in the entire populations were respectively 0.2732 , $0.2528,0.0746$ and 6.2042 . The $\mathrm{G}_{\mathrm{ST}}$ value recorded 0.0746 indicating about $7 \%$ of the total genetic divergence among the populations and the remaining 93\% within the populations. Across the DAMD markers, NPL and PPL ranged from 8 to 14 and 53.33-86.67, respectively. Effective number of alleles, $\mathrm{H}$ and I values produced were $1.2914 \pm 0.3779-1.4746 \pm 0.3140,0.1720 \pm$ 
Table 2 Analysis of genetic diversity of 15 accessions of Capsicum annuum species using start codon targeted

\begin{tabular}{llll}
\hline Pepper Accession & Effective no of alleles, Ne & Nei's genetic diversity, H & Shannon's information index, I \\
\hline CrPe-1 & 1.7082 & 0.4146 & 0.6051 \\
CrPe-2 & 1.9996 & 0.4999 & 0.6931 \\
CrPe-3 & 1.8281 & 0.4530 & 0.6454 \\
CrPe-4 & 1.0270 & 0.0263 & 0.0708 \\
CrPe-5 & 1.7705 & 0.4352 & 0.6269 \\
CrPe-6 & 1.9023 & 0.4743 & 0.6672 \\
CrPe-7 & 1.7399 & 0.4252 & 0.6164 \\
CrPe-8 & 1.9231 & 0.4800 & 0.6730 \\
Sub-mean & 1.7373 & 0.4011 & 0.5747 \\
EbPe-1 & 1.9231 & 0.4800 & 0.6730 \\
EbPe-2 & 1.6423 & 0.3911 & 0.5799 \\
EbPe-3 & 1.6423 & 0.3911 & 0.5799 \\
EbPe-4 & 1.2037 & 0.1692 & 0.3102 \\
EbPe-5 & 1.7705 & 0.4352 & 0.6269 \\
EbPe-6 & 1.7399 & 0.4252 & 0.6164 \\
EbPe-7 & 1.6756 & 0.4032 & 0.5930 \\
Sub-mean & 1.6568 & 0.3850 & 0.5685 \\
Overall mean & 1.6971 & 0.5936 & 0.8590 \\
\hline CPeCross Rver & &
\end{tabular}

CrPe Cross River State pepper accessions and EbPe from Ebonyi State

Table 3 Genetic diversity and differentiation in the accessions of Capsicum annuum using start codon targeted

\begin{tabular}{lllll}
\hline Pepper Accession & $\mathrm{Ht}$ & $\mathrm{Hs}$ & $\mathrm{G}$ ST & $\mathrm{Nm}$ \\
\hline CrPe-1 & 0.4146 & 0.3840 & 0.0738 & 6.2791 \\
CrPe-2 & 0.4999 & 0.4907 & 0.0185 & 26.5385 \\
CrPe-3 & 0.4530 & 0.4089 & 0.0973 & 4.6371 \\
CrPe-4 & 0.0263 & 0.0249 & 0.0541 & 8.7500 \\
CrPe-5 & 0.4352 & 0.4124 & 0.0523 & 9.0625 \\
CrPe-6 & 0.4743 & 0.4409 & 0.0705 & 6.5957 \\
CrPe-7 & 0.4252 & 0.4018 & 0.0552 & 8.5606 \\
CrPe-8 & 0.4800 & 0.4196 & 0.1259 & 3.4706 \\
Sub-mean & 0.4011 & 0.3729 & 0.0685 & 9.2368 \\
EbPe-1 & 0.4800 & 0.4338 & 0.0963 & 4.6923 \\
EbPe-2 & 0.3911 & 0.2916 & 0.2545 & 1.4643 \\
EbPe-3 & 0.3911 & 0.3520 & 0.1000 & 4.5000 \\
EbPe-4 & 0.1692 & 0.0996 & 0.4118 & 0.7143 \\
EbPe-5 & 0.4352 & 0.3804 & 0.1258 & 3.4740 \\
EbPe-6 & 0.4252 & 0.3698 & 0.1304 & 3.3333 \\
EbPe-7 & 0.4032 & 0.3129 & 0.2240 & 1.7323 \\
Sub-mean & 0.3850 & 0.3200 & 0.1918 & 2.8444 \\
Overall mean & 0.3936 & 0.3482 & 0.1153 & 3.8375 \\
St. Dev & 0.0163 & 0.0161 & & \\
\hline$H$ & & & & \\
\hline
\end{tabular}

$H t$ total gene diversity, $H s$ gene diversity within population, $G_{S T}$ coefficient of gene differentiation and $\mathrm{Nm}$ estimate of gene flow from $\mathrm{G}_{\mathrm{ST}}$ or Gcs. E.g., $\mathrm{Nm}=$ $0.5\left(1-\mathrm{G}_{\mathrm{ST}}\right) / \mathrm{G}_{\mathrm{ST}}, \mathrm{CrPe}$ population of pepper from Cross River State and $\mathrm{EbPe}$ from Ebonyi State
$1.9880-0.3013 \pm 0.1229$ and $0.2620 \pm 0.2835-0.4656 \pm$ 0.1671 , respectively (Additional file 8 : Table S6).

\section{Comparison of SCOT and DAMD data obtained from the accessions of Capsicum annuum}

Results obtained from the two markers were compared (Additional file 9: Table S7). Based on the dendrograms, five and three major groups were obtained from SCoT and DAMD data, respectively, while five clusters based on PCA were detected in each of the markers. A total of 57 alleles were found using SCoT markers, while 46 alleles were linked to DAMD markers. The mean numbers of alleles identified in SCoT and DAMD markers were 12.0000 and 10.1667, respectively. Mean genetic diversity values were respectively 0.8815 for SCoT and 0.8430 for DAMD markers, while their mean PICs were respectively 0.8709 and 0.8268 . The average major allele frequency associated with the SCoT markers was 0.20000 , while that of the DAMD markers yielded 0.2556. The total numbers of polymorphic loci were 64 and 56 for SCoT and DAMD, respectively. The percentage polymorphic loci obtained with the SCoT markers ranged from $80.00-95.73 \%$ but $53.33-86.67 \%$ with the DAMD markers. Mean of Ne was 1.6971 for SCoT markers and 1.4268 for the DAMD markers. The mean value of $\mathrm{H}$ obtained with SCoT markers was 0.5936, while DAMD produced 0.4081 . The mean of I obtained with the SCoT and DAMD markers were 0.8590 and 0.6466 , respectively. 


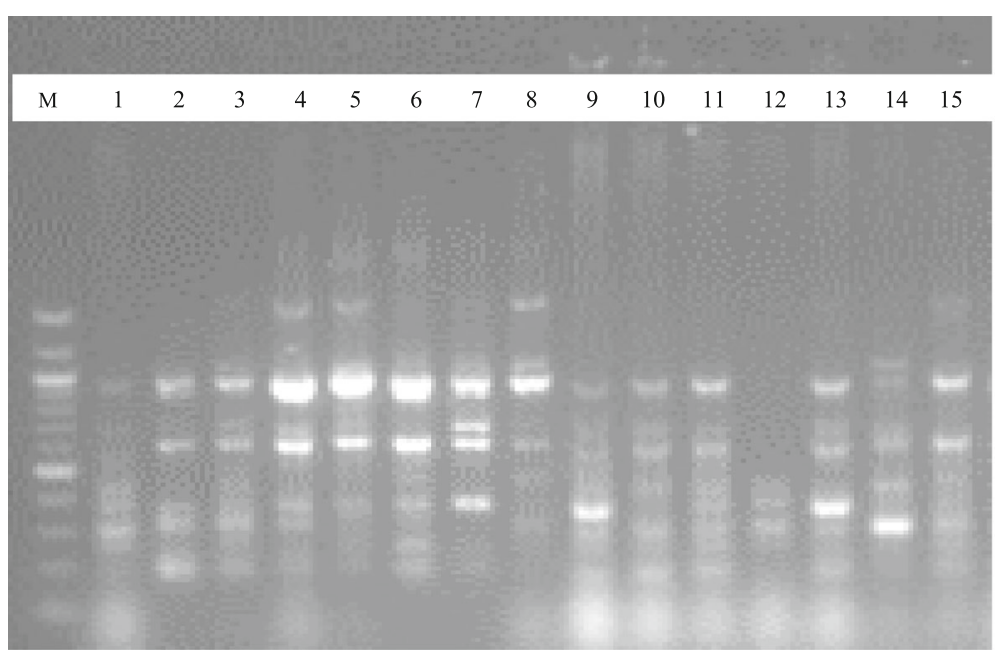

Fig. 4 Fifteen Capsicum annuum DNA samples amplified with DAMD25 marker. $M=100$ bp DNA ladder; 1-8 =C. annuum accessions from different locations of Cross River State, Nigeria; and 9-15=C. annuum accessions from Ebonyi State, Nigeria

Also, $\mathrm{Ht}$ recorded in the $\mathrm{SCoT}$ marker data was 0.3936 , while DAMD had 0.2732. The value of $\mathrm{Hs}$ in SCoT was 0.3482 and DAMD yielded 0.2528. In SCoT marker data matrix, the $\mathrm{G}_{\mathrm{ST}}$ was 0.1153 (12\% of the total genetic divergence among the populations and $88 \%$ within the populations) and 0.0746 (7\% of the total genetic divergence among the populations and $93 \%$ within the populations) in DAMD, while the Nm obtained with the SCoT marker data was 3.8375 and 0.6 .2042 for the DAMD markers.

\section{Discussion}

The efficacy of molecular marker systems for characterization and diversity assessment of C. annuиm is very important for breeding, improvement and conservation purposes. The estimation of genetic diversity among accessions is beneficial for the utilization and maintenance of genetic resources. Genetic estimation helps to widen the genetic base of the cultivars and prevents gene insertion or deletion [62]. Assessing degree of genetic indices in populations of crops within germplasm using easily affordable and high-proof reading molecular markers could be a useful technique for characterization, detection and selection of novel accessions in a plant breeding-based approach for germplasm conservation of viable genetic resources with potential traits $[63,64]$. It will also aid in the verification of identified morphological traits for adequate discrimination of

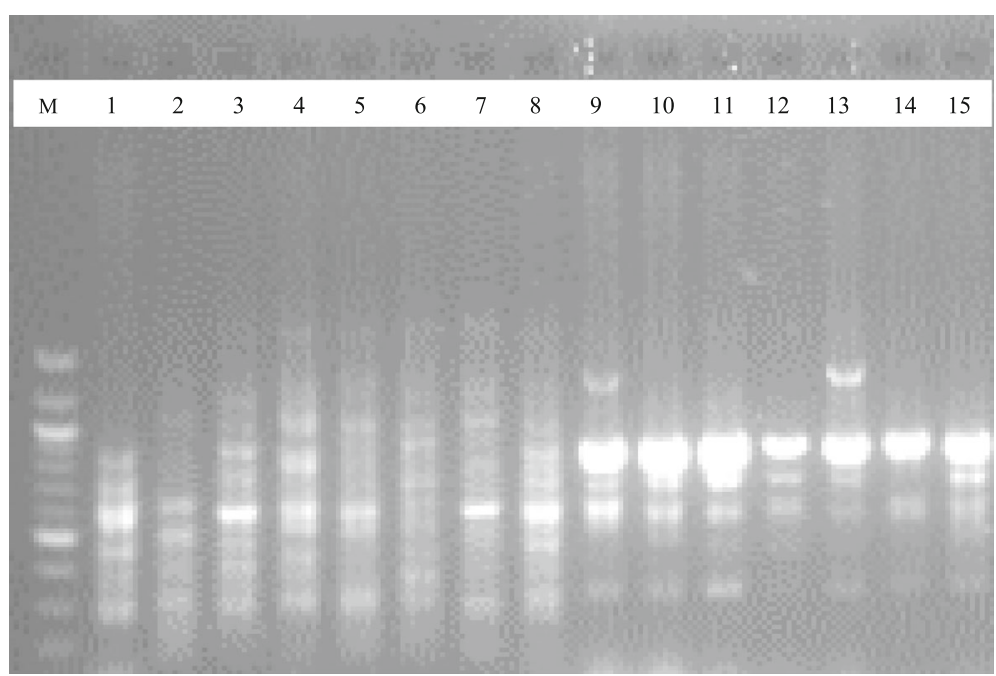

Fig. 5 Fifteen Capsicum annuum DNA samples amplified with DAMD16 marker. $M=100$ bp DNA ladder; 1-8 =C. annuum accessions from different locations of Cross River State, Nigeria; and 9-15 =C. annuum accessions from Ebonyi State, Nigeria 


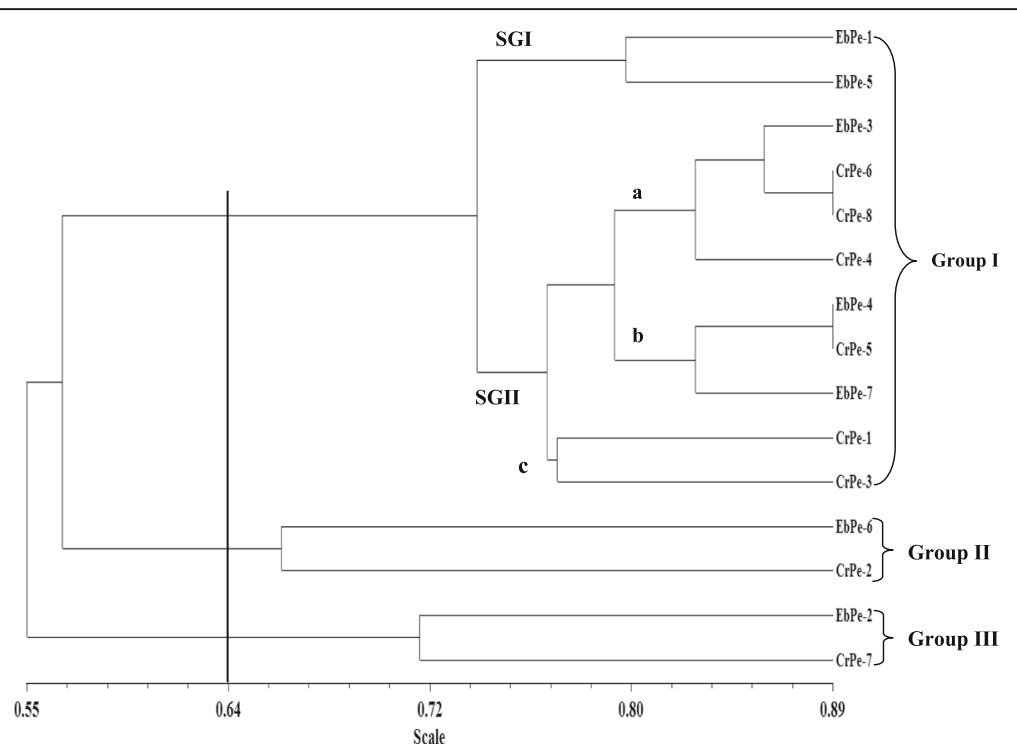

Fig. 6 Dendrogram of 15 accessions of Capsicum annuum amplified with directed amplified minisatellite DNA markers

genotypes [65]. Many molecular markers have been used to explore the genetic ingenuity of planting materials and to identify significant phenotypic characters associated with them. Molecular markers of different types have been applied in the characterization, mapping and study of genetic diversity of pepper [23-33]. In this study, SCoT and DMAD markers were explored to comparatively assess the genetic diversity of pepper accessions from Cross River and Ebonyi States of Nigeria. This became necessary since it is widely accepted that comparing different markers to study genetic diversity can be more resourceful and informative in the classification and selection of the best resolving markers [66].

Our results revealed that both SCoT and DAMD markers have high degree of discriminating potential on the pepper accessions as shown by the measured genetic diversity parameters (number of alleles per primer, PIC values, percent polymorphism, and polymorphic loci). Each of the markers, SCoT and DAMD resolved the accessions into five and three major groups, respectively using dendrogram and five clusters each based on PCA. The accessions were differently grouped by the two different sets of markers and this is possible due to variation in the accessibility of different genomic loci by the markers. Two major groups were identified in a study involving 149 black pepper germplasms using EST-SSR markers [33], while five major groups were detected in 30 accessions using SCoT markers [31] and this is in agreement with our findings with SCoT markers. Further, two major groups were found in a study involving 11 Chili pepper using AFLP markers [67]. The discrepancy between dendrograms and clusters of the pepper accessions by the two marker approaches could be linked to the different nature of the markers with regards to their regions of coverage in the genome, level of polymorphism and the number of loci involved as earlier reported $[68,69]$. This further demonstrates the significance of total number of identifiable loci and degree of coverage in the whole genome to actualize the required genetic relatedness within accessions [68].

On the part of genetic diversity assessment, SCoT markers identified those from Cross River State to be more genetically isolated compared to those from Ebonyi as a result of higher genetic indices inherent in them.

Table 4 Allele frequency, number of alleles, gene and polymorphic information content of directed amplified minisatellite DNA

\begin{tabular}{|c|c|c|c|c|c|}
\hline Marker & Major allele frequency & No. of obs. & Allele No & Gene diversity & $\mathrm{PIC}$ \\
\hline DAMD17R & 0.2000 & 15.0000 & 9.0000 & 0.8711 & 0.8574 \\
\hline DAMD13 & 0.1333 & 15.0000 & 11.0000 & 0.8978 & 0.8887 \\
\hline DAMD16 & 0.2667 & 15.0000 & 11.0000 & 0.8711 & 0.8600 \\
\hline DAMD25 & 0.4667 & 15.0000 & 6.0000 & 0.6933 & 0.6519 \\
\hline DAMD1F & 0.4000 & 15.0000 & 9.0000 & 0.7911 & 0.7735 \\
\hline Mean & 0.2556 & 15.0000 & 10.1667 & 0.8430 & 0.8268 \\
\hline
\end{tabular}


Table 5 Analysis of genetic diversity of 15 accessions of Capsicum annuum using directed amplified minisatellite DNA

\begin{tabular}{llll}
\hline Pepper Accession & Effective no of alleles, Ne & Nei's genetic diversity, H & Shannon's information index, I \\
\hline CrPe-1 & 1.4188 & 0.2952 & 0.4714 \\
CrPe-2 & 1.7241 & 0.4200 & 0.6109 \\
CrPe-3 & 1.3272 & 0.2408 & 0.4050 \\
CrPe-4 & 1.2195 & 0.1800 & 0.3251 \\
CrPe-5 & 1.1726 & 0.1472 & 0.2788 \\
CrPe-6 & 1.2677 & 0.2112 & 0.3669 \\
CrPe-7 & 1.8142 & 0.4488 & 0.6410 \\
CrPe-8 & 1.2677 & 0.2112 & 0.3669 \\
Sub-mean & 1.4015 & 0.2693 & 0.4333 \\
EbPe-1 & 1.3676 & 0.2688 & 0.4397 \\
EbPe-2 & 1.9501 & 0.4872 & 0.6803 \\
EbPe-3 & 1.4188 & 0.2952 & 0.4714 \\
EbPe-4 & 1.0000 & 0.0000 & 0.0000 \\
EbPe-5 & 1.3172 & 0.2408 & 0.4050 \\
EbPe-6 & 1.8911 & 0.4712 & 0.6641 \\
EbPe-7 & 1.2195 & 0.1800 & 0.3251 \\
Sub-mean & 1.4520 & 0.2776 & 0.4265 \\
Overall mean & 1.4268 & 0.4081 & 0.6466 \\
\hline
\end{tabular}

CrPe Cross River State pepper accession and EbPe Ebonyi State pepper accession

Table 6 Genetic diversity and differentiation in the accessions of Capsicum annuum using directed amplified minisatellite DNA markers

\begin{tabular}{|c|c|c|c|c|}
\hline Pepper Accession & $\mathrm{Ht}$ & $\mathrm{Hs}$ & $\mathrm{G}_{S T}$ & $\mathrm{Nm}$ \\
\hline $\mathrm{CrPe}-1$ & 0.2952 & 0.2600 & 0.1192 & 3.6932 \\
\hline CrPe-2 & 0.4200 & 0.4040 & 0.0381 & 12.6250 \\
\hline CrPe-3 & 0.2408 & 0.2200 & 0.0864 & 5.2885 \\
\hline CrPe-4 & 0.1800 & 0.1560 & 0.1333 & 3.2500 \\
\hline CrPe-5 & 0.1472 & 0.1280 & 0.1304 & 3.3333 \\
\hline CrPe-6 & 0.2112 & 0.1840 & 0.1288 & 3.3824 \\
\hline CrPe-7 & 0.4488 & 0.4360 & 0.0285 & 17.0312 \\
\hline CrPe-8 & 0.2112 & 0.1840 & 0.1288 & 3.3824 \\
\hline Sub-mean & 0.2693 & 0.2465 & 0.0992 & 6.4983 \\
\hline EbPe-1 & 0.2688 & 0.2400 & 0.1071 & 4.1667 \\
\hline EbPe-2 & 0.4872 & 0.4840 & 0.0066 & 75.6250 \\
\hline EbPe-3 & 0.2952 & 0.2840 & 0.0379 & 12.6786 \\
\hline EbPe-4 & 0.0000 & 0.0000 & 0.0000 & 0.0000 \\
\hline EbPe-5 & 0.2408 & 0.2360 & 0.0199 & 24.5833 \\
\hline EbPe-6 & 0.4712 & 0.4120 & 0.1256 & 3.4797 \\
\hline EbPe-7 & 0.1800 & 0.1640 & 0.0889 & 5.1250 \\
\hline Sub-mean & 0.2776 & 0.2600 & 0.0551 & 17.9512 \\
\hline Overall mean & 0.2732 & 0.2528 & 0.0746 & 6.2042 \\
\hline St. Dev & 0.0183 & 0.0174 & & \\
\hline
\end{tabular}

$H t$ total gene diversity, $H_{s}$ gene diversity within population, $G_{S T}$ coefficient of gene differentiation and $\mathrm{Nm}$ estimate of gene flow from $\mathrm{G}_{\mathrm{ST}}$ or Gcs. E.g., $\mathrm{Nm}$ $0.5\left(1-G_{S T}\right) / G_{S T}, C r P e$ population of pepper from Cross River State, EbPe population of pepper from Ebonyi State
On the other hand, DAMD markers classified accessions from Ebonyi to be more diverse than those from Cross River State. It has been reported that $\mathrm{H}$ and I are major parameters in genetic diversity studies since $\mathrm{H}$ estimates genetic diversity within and between accessions, while I is for genetic diversity within and between populations regardless of the number of accessions accessed [69, 70]. Based on the higher values in the basic parameters for genetic diversity assessment achieved from the markers (SCoT: $\mathrm{H}=0.5936, \mathrm{I}=0.8590$; DAMD: $\mathrm{H}=0.4081, \mathrm{I}=$ 0.6466), SCoT markers were found to be more efficient than DAMD and this further suggests that accessions from Cross River State are more genetically diverse than those obtained from Ebonyi State. In the present study, $\mathrm{H}$ and $\mathrm{I}$, which are independent of number of samples being considered [70], are high in the two markers but higher in SCoT. These identified genetic parameters are higher than the ones obtained from a previous report, where $\mathrm{H}$, I and PIC generated from 30 accessions of pepper using six SCoT markers were $0.2550,0.4030$ and 0.2120 , respectively [31]. This difference could be linked to various marker techniques assessing different positions of the genome as previously reported in another combined marker-technique involving ISSR and RAPD [71].

The total potential numbers of identified alleles (SCoT: 57 with mean of 12.0000; DAMD: 46 with mean of 10.1667) in this study demonstrated high allelic richness and genetic diversity within the accessions thereby 
contributing meaningfully to the genetic diversity among the accessions. The number of alleles detected with the SCoT markers is highly comparable to 53 alleles recently reported using six SCoT and six ISSR markers in 30 accessions of pepper [31] but a bit higher than the one identified with DAMD markers in the present study. In addition, the number of alleles generated with SCoT is lower but its allelic mean value is almost in agreement with a previous report involving 151 alleles, with a mean value of 10.0600 in 39 female Jojoba (Simmondsia chinensis (Link) Schneider) genotypes amplified with 15 SCoT markers were identified [72]. The obtained PIC using SCoT and DAMD markers were very high but higher in SCoT (PIC range: 0.7735-0.9193; mean: 0.8709 ) than DAMD (PIC range: 0.6519-0.8887; mean: 0.8268 ). In other genetic studies, molecular markers with PIC values between $0.4800-0.8000$, with a mean of 0.7200 or PIC values above $50 \%$ were highly informative and polymorphic ones [73-75]. Both markers demonstrated PIC values higher than the previously reported ones in other crops of female Jojoba genotypes analyzed with SCoT markers (PIC range: 0.22-0.4800; mean: 0.4000) [72], Musa acuminata with DAMD (PIC range: 0.2900-0.4200; mean: 0.3500) [47] and grapevine cultivars with DAMD (PIC range: 0.3800-0.4900; mean: 0.4400) [76]. The observed mean values of PIC in DAMD is less than that of SCoT which shows that the SCoT markers evaluated are more informative than the DAMD ones. These markers exhibited high percentage polymorphisms (80-95.73\% for SCoT and 53.33-86.67\% for DAMD markers) in the accessions studied as previously reported on 30 accessions of pepper using SCoT (75-100\%) and ISSR (70-100\%) [31]. In addition, 33$100 \%$ polymorphism was detected from 40 landrace chickpea (Cicer arietinum L.) genotypes with SCoT and DAMD markers [77]. The percentage polymorphism obtained is generally high for both marker types, with the SCoT markers revealing higher polymorphisms than DAMD, thereby indicating the efficacious nature of the SCoT marker systems used.

High number of alleles from the two marker polymorphic loci (SCoT: 64; DAMD: 56) demonstrated that they contributed meaningfully to the genetic diversity among these accessions of pepper. This is in contrast with previous reports where 160 alleles were identified with EST-SSR markers in 148 accessions of black pepper [33]. Similarly, 75 and 53 high numbers of alleles of detected from 64 and 30 accessions of pepper were respectively high $[28,31]$. The identified genetic parameters from the two markers (SCoT: $\mathrm{Ne}=1.6971, \mathrm{H}=0.5936$ and $\mathrm{I}=$ 0.8590; DAMD: $\mathrm{Ne}=1.4268, \mathrm{H}=0.4081$ and $\mathrm{I}=0.6466$ ) are quite high but higher in SCoT, thereby classifying the accessions from Cross River as the most genetically dissimilar compared to those collected from Ebonyi. In the present study, the identified values of these vital genetic indices are higher than the ones obtained from earlier studies on 30 accessions of pepper using $\mathrm{SCoT}(\mathrm{H}=$ $0.2550, \mathrm{I}=0.4030)$ and ISSR $(\mathrm{H}=0.3060, \mathrm{I}=0.4590)$ [31]. The obtained population indices in these accessions using SCoT $\left(\mathrm{Ht}=0.3936, \mathrm{Hs}=0.3482, \mathrm{G}_{\mathrm{ST}}=0.1153\right.$ and $\mathrm{Nm}=$ 3.8375) and DAMD $\left(\mathrm{Ht}=0.2732, \mathrm{Hs}=0.2528, \mathrm{G}_{\mathrm{ST}}=\right.$ 0.0746 and $\mathrm{Nm}=6.2042$ ) were higher than the ones previously reported in black pepper analyzed with EST-SSR [33]., in pepper accessions with EST-SSR and SCoT [31]., and in wild and domesticated populations of ramie amplified with SCoT [46]. The two marker techniques explicitly detected wide genetic diversity within and between the accessions evaluated, with the SCoT markers showing higher potential in discriminating them.

According to Nei [78], $\mathrm{G}_{\mathrm{ST}}$ is classified as low when its value is $<0.0500$, medium when it is $0.0500<\mathrm{G}_{\mathrm{ST}}<$ 0.1500 and high when $G_{\mathrm{ST}}>0.1500$. The obtained values of $\mathrm{G}_{\mathrm{ST}}$ in the two marker systems ( $\mathrm{SCoT}=0.1153$; DAMD: $=0.0746$ ) indicate that only about 7 and $12 \%$ of the total genetic divergence exist and this may be due to source locations of the accessions (external factors), while 93 and $88 \%$ were contributed by genotypic variations within the populations possibly due to internal factors. This finding is consistent with the previous reports $[79,80]$, where $\mathrm{G}_{\text {ST }}$ values of 0.1700 and 0.3200 were respectively identified but lower than the ones obtained from chili pepper using AFLP $\left(\mathrm{G}_{\mathrm{ST}}=0.8600\right)$ [67], Commiphora wightii (RAPD: $\mathrm{G}_{\mathrm{ST}}=0.5800$ ) [81], Torreya jackii Chun (ISSR: $\mathrm{G}_{\mathrm{ST}}=0.6300$ ) [82] and Curculigo latifolia (SCoT: $\mathrm{G}_{\mathrm{ST}}=0.4800$ ) [83]. The noted differences could be attributable to the number of samples analyzed and the nature of the plant genome assessed. The overall genetic variation $(\mathrm{Ht}=0.2732)$ obtained in the whole population with the DAMD marker was lower than the one of intra-population genetic diversity $(\mathrm{Hs}=0.2528)$. On the part of SCoT marker, 0.3936 of $\mathrm{Ht}$ was higher than $\mathrm{Hs}$ generated as 0.3482 . It has been known that the $\mathrm{Nm}$ is low when $\mathrm{Nm}<1$, moderate $(\mathrm{Nm}>1)$ and extensive $(\mathrm{Nm}>4)$ in nature [84]. The recorded $\mathrm{Nm}$ in this present study indicates extensiveness in $\mathrm{SCoT}(\mathrm{Nm}=$ 3.8375) and extremely extensive in DAMD $(\mathrm{Nm}=$ 6.2042) gene flow among the populations. This also exhibits a great deal of variation and rich genetic diversity within the populations from different locations across Cross River and Ebonyi States of Nigeria and these unique accessions could be utilized in further hybridization processes in breeding program. This high genetic differentiation within populations/accessions is possibly linked to outcrossing pollination process and exchange of genetic materials as reported in Begonia species involving microsatellite markers [85]. In population genetics, the estimation of gene flow with respect to the number of individual genes involves migration of 
one population to the other and per generation. It induces population differentiation and it is possible to prevent substantial differentiation in a population as a result of genetic drift if the gene flow is greater than 1 $(\mathrm{Nm}>1)$ [86, 87]. Compared to the outcome of this present study, lower values of $\mathrm{G}_{\mathrm{ST}}$ and $\mathrm{Nm}$ have been reported in other crop species including Rhamnus persicifolia Moris and Lilium cernuum with SSR markers [88, 89].

\section{Conclusion}

Our research revealed that both SCoT and DAMD markers demonstrated a high discriminatory role in the dissection of genetic diversity within the accessions of $C$. annuum from both Ebonyi and Cross River States. However, SCoT markers were found more discriminatory and informative than DAMD markers following the higher genetic diversity indices inherent in SCoT, thereby classifying the accessions from Cross River State as more genetically diverse than those from Ebonyi. The SCoT markers generally were more efficacious by demonstrating higher parameters of all the genetic diversity indices deployed than DAMD markers, except major allele frequency, allele count, allele frequency and gene flow, which may not be good indicators when accessing genetic diversity in $C$. annuum species. Selection from the accessions of the unique clusters and genetic indicators as revealed by the polymorphic SCoT markers could serve as stocks in a hybridization process to achieve superior hybrids capable of withstanding genetic barriers, environmental stressors and novel gene exchange in breeding programs of $C$. annuum.

\section{Supplementary information}

Supplementary information accompanies this paper at https://doi.org/10. 1186/s41065-019-0108-6.

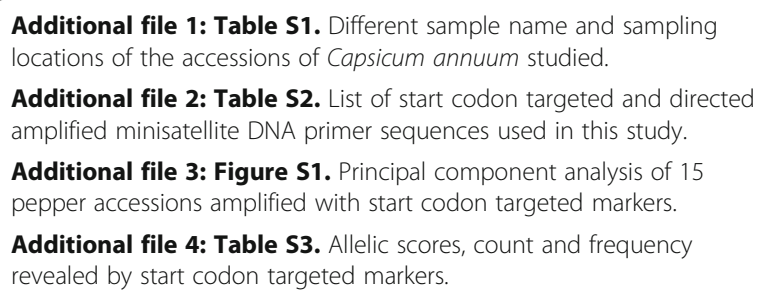

Additional file 5: Table S4. Genetic diversity within Cross River and Ebonyi States Capsicum annuum species accessions using start codon targeted markers.

Additional file 6: Figure S2. Principal component analysis of 15 accessions of pepper amplified with directed amplified minisatellite DNA markers.

Additional file 7: Table S5. Allelic score, count and frequency of directed amplified minisatellite DNA markers.

Additional file 8: Table S6. Genetic diversity within accessions of pepper collected Cross River and Ebonyi States and amplified using directed amplified minisatellite DNA markers.
Additional file 9: Table S7. Summary of comparisons of start codon targeted and directed amplified minisatellite DNA marker data in pepper accessions.

\section{Abbreviations}

AFLP: Amplified fragment length polymorphism;

CTAB: Cetyltrimethylammonium bromide; DAMD: Directed amplified minisatellite DNA; DEPC: Diethylpyrocarbonate; EB: Extraction buffer; EDTA: Ethylenediamme tetraacetic acid; EST: Expressed sequence tag; GST: Coefficient of differentiation; H: Nei's genetic diversity; Hs: Genetic diversity within the population; Ht: Total genetic diversity; I: Shannon's information index; ISSR: Inter-simple sequence repeat; LGA: Local Government Authority; Ne: Effective number of alleles; Nm: Estimate of gene flow; NPL: Number of polymorphic loci'; PCA: Principal component analysis; PCR: Polymerase chain reaction; PIC: Polymorphic information content; PPL: Percentage polymorphic loci; RAPD: Random amplified polymorphic DNA; RFLP: Restriction fragment length polymorphism; SCOT: Start codon targeted; SNP: Single nucleotide polymorphism; SSR: Simple sequence repeat; UPGMA: Unweighted Pair Group Method with Arithmetic Mean

\section{Acknowledgements}

The authors are grateful to Biotechnology Research and Development Center (BRDC), Ebonyi State University, Abakaliki, Nigeria for providing technical support and facilities used in this research. We also appreciate the efforts of Ukpai Stephen and Alobi Richard for their assistance in the collection of the accessions of $C$. annuum from different locations of Cross River and Ebonyi States.

\section{Authors' contributions}

All authors were jointly involved in designing the project. DOI and CAA did the literature search, isolated samples, and carried out study compilation. Data analyses were performed by DOI and reviewed by GA and GNU. DOI developed the first draft of the manuscript. All authors read the manuscript and approved the final copy of it.

\section{Funding}

No funding was received to conduct this study.

\section{Availability of data and materials}

The dataset(s) supporting the conclusions of this article is (are) included within the article (and its additional file(s)).

Ethics approval and consent to participate

Consent was obtained from farmers before entering into their individual farms for sample collection.

\section{Consent for publication \\ Not applicable.}

\section{Competing interests}

The authors declare that they have no competing interests.

\section{Author details}

'Department of Biotechnology, Faculty of Science, Ebonyi State University, Abakaliki 053, Nigeria. ${ }^{2}$ Biotechnology and Research Development Centre, Ebonyi State University, Abakaliki, Ebonyi State 053, Nigeria. ${ }^{3}$ Department of Natural Sciences, Bowie State University, 14000 Jericho Park Road, Bowie, Maryland 20715, USA.

Received: 19 February 2019 Accepted: 24 September 2019 Published online: 16 October 2019

\section{References}

1. Greenleaf WH. Pepper breeding. In: Bassett MJ, editor. Breeding vegetable crops. Westport: AVI Pub. Co.; 1986. p. 67-134.

2. Bosland PW, Votava EJ. Peppers: Vegetable and spice capsicums, vol. 7. United Kingdom and New York: Oxon Publishing; 2000. p. 112-32.

3. Perry L, Dickau R, Zarrillo S, Holst I, Pearsall DM, Piperno DR, Berman MJ, Cooke RG, Rademaker K, Ranere AJ, Raymond S, Sandweiss DH, Scaramelli F, 
Tarble K, Zeidler JA. Starch fossils and the domestication and dispersal of chili peppers (Capsicum spp. L.) in the American. Sci. 2007;315:986-8.

4. Dagnoko S, Yaro-Diarisso N, Sanogo PN, Adetula O, Dolo-Nantoume A, Gamby-Toure K, Traore-Thera A, Katile S, Diallo-Ba D. Overview of pepper (Capsicum spp.) breeding in West Africa. Afr J Agric Res. 2013;8(13):1108-14.

5. Singh N, Bajpai R, Mahar KS, Tiwari V, Upreti DK, Rana TS. ISSR and DAMD markers revealed high genetic variability within Flavoparmelia caperata in Western Himalaya (India). Physiol Mol Biol Plants. 2014;20(4):501-8.

6. Daskalov AM, Poulos JM. Updated Capsicum gene list: mutation breeding in Capsicum and eggplant. New Zealand research center for genetic markers. New Zealand Dalton press. 2015;13:15-26.

7. Naegele PR, Mitchell J, Hausbeck KM. Genetic diversity, population structure, and heritability of fruit traits in Capsicum annuum. PLoS One. 2016;11(7): e0156969. https://doi.org/10.1371/journal. pone.0156969.

8. Hill TA, Ashrafi H, Reyes-Chin-Wo S, Yao J, Stoffel K, Truco MA, Kozik A, Michelmore RW, Deynze AV. Characterization of Capsicum annuum genetic diversity and population structure based on parallel polymorphism discovery with a 30K unigene pepper GeneChip. PLoS One. 2013;8(2):1-16.

9. Eshbaugh WH. Peppers: history and exploitation of a serendipitous new crop discovery. In: Janick J, Simon JE, editors. New crops. New York: Wiley; 1993. p. 132-9.

10. Grubben GJH, El Tahir IM. Capsicum annuum L. In: Grubben GJH, Denton OA, editors. PROTA 2: Vegetables/Légumes. [CD-Rom]. Wageningen: PROTA; 2004

11. Olmstead RG, Bohs L, Migid HA, Santiago-Valentin E, Garcia VF, Collier SM. A molecular phylogeny of the solanaceae. Taxon. 2008;57:1159-81.

12. Costa LV, Lopes R, Lopes MTG, De Figueiredo AF, Barros WS, Alves SRM. Cross compatibility of domesticated hot pepper and cultivated sweet pepper. Crop Breed Appl Biotechnol. 2009;9:37-44.

13. Andrews J. Peppers: the domesticated capsicums. Austin: University of Texas Press; 1984.

14. USDA-ARS. National Genetic Resources Program. Germplasm Resources Information Network (GRIN). Beltsville, Maryland: National Germplasm Resources Laboratory, Beltsville, Maryland, 2011. Available:http://www. arsgrin.gov/cgi-bin/npgs/html/exsplist.pl. Accessed 23 May 2015.

15. Pickersgill B. Domestication of plants in the Americas: insights from Mendelian and molecular genetics. Ann Bot. 2007;100:925-40.

16. Arumuganathan $\mathrm{K}$, Earle E. Nuclear DNA content of some important plant species. Plant Mol Biol Report. 1991;9:208-18.

17. Moscone EA, Baranyi M, Ebert I, Greilhuber J, Ehrendorfer F, Hunziker AT. Analysis of nuclear DNA content in Capsicum (Solanaceae) by flow cytometry and Feulgen densitometry. Annals Bot. 2003;92:21-9.

18. Stewart C, Kang BC, Liu K, Mazourek M, Moore SL, Yoo EY, Kim B, Paran I, Jahn MM. The pun1gene for pungency in pepper encodes a putative acyltransferase. Plant J. 2005;42:675-88.

19. Paran I, van der Knaap E. Genetic and molecular regulation of fruit and plant domestication traits in tomato and pepper. J Exp Bot. 2007;58:3841-52.

20. Popovsky S, Paran I. Molecular analysis of the Y locus in pepper. It's relation to Capsanthin-capsorubin synthase and to fruit colour. Theor Appl Genet. 2000;101:86-9.

21. Govindaraj M, Vetriventhan M, Srinivasan M. Importance of genetic diversity assessment in crop plants and its recent advances: an overview of its analytical perspectives. Genet Res International. 2015;2014:1-14.

22. Igwe DO, Afiukwa CA, Ubi BE, Ogbu Kl, Ojuederie OB, Ude GN. Assessment of genetic diversity in Vigna unguiculata L. (Walp) accessions using intersimple sequence repeat (ISSR) and start codon targeted (SCOT) polymorphic markers. BMC Genet. 2007;18:98.

23. Tam SM, Lefebvre V, Palloix A, Sage-Palloix A-M, Mhiri C, Grandbastien M-A. LTR-retrotransposons Tnt1 and T135 markers reveal genetic diversity and evolutionary relationships of domesticated peppers. Theor Appl Genet. 2009;119:973-89.

24. Adetula OA. Genetic diversity of Capsicum using random amplified polymorphic DNAs. Afr J Biotechnol. 2006;5:120-2.

25. Akbar N, Ahmad H, Ghafoor S, Begum K, Afridi SG, Muhammad I, Khan IA. Estimation of genetic diversity in Capsicum germplasm using randomly amplified polymorphic DNA. Asian J Agri Sci. 2010;2:53-6.

26. Rodrigues KF, Tam HK. Molecular markers for Capsicum frutescens varieties cultivated in Borneo. J Plant Breed Crop Sci. 2010;6:165-7.

27. González-Jara P, Moreno-Letelier, Fraile A, Piñero A, García-Arenal F. Impact of human management on the genetic variation of wild pepper, Capsicum annuum var. glabriusculum. PLoS One. 2011;6:e28715.
28. Dhaliwal MS, Yadav A, Jindal SK. Molecular characterization and diversity analysis in Chilli pepper using simple sequence repeats (SSR) markers. Afr J Biotechnol. 2014;13(31):3137-43.

29. Moses M, Umaharan P, Dayanandan S. Microsatellite based analysis of the genetic structure and diversity of Capsicum chinense in the Neotropics. Genet Resour Crop Evol. 2014;61:741-55.

30. Krishnamurthy SL, Prashanth Y, Rao AM, Reddy KM, Ramachandra R. Assessment of AFLP marker based genetic diversity in Chilli (Capsicum annuum L. and C. baccatum L.). Indian J Biotechnol. 2015;14:49-54.

31. Tsaballa A, Ganopoulos I, Timplalexi A, Aliki X, Bosmali I, Irini N-O, Athanasios T, Madesis P. Molecular characterization of Greek pepper (Capsicum annuum L.) landraces with neutral (ISSR) and gene-based (SCOT and EST-SSR) molecular markers. Biochem Sys Ecol. 2015;59:256e263.

32. Taranto F, D'Agostino N, Greco B, Cardi T, Tripodi P. Genome-wide SNP discovery and population structure analysis in pepper (Capsicum annuum) using genotyping by sequencing. BMC Genomics. 2016;17:943.

33. Wu BD, Fan R, Hu LS, Wu HS, Hao CY. Genetic diversity in the germplasm of black pepper determined by EST-SSR markers. Genet Mol Res, DOI. 2016; 15(1):gmr.15018099 https://doi.org/10.4238/gmr.15018099.

34. Manivannan A, Jin-Hee K, Eun-Young Y, Yul-Kyun A, Eun-Su L, Choi S, Kim D. Next-generation sequencing approaches in genome-wide discovery of single nucleotide polymorphism markers associated with pungency and disease resistance in pepper. BioMed Res Int. 2018;5646213:7.

35. Sharmin A, Hoque ME, Haque MM, Khatun F. Molecular diversity analysis of some chilli (Capsicum spp.) genotypes using SSR markers. Am J Plant Sci. 2018;9:368-79.

36. Nicolai M, Cantet M, Lefebvre V, Sage-Palloix AM, Palloix A. Genotyping a large collection of pepper (Capsicum spp.) with SSR loci brings new evidence for the wild origin of cultivated C. annuum and the structuring of genetic diversity by human selection of cultivar types. Genet Resour Crop Evol. 2013;60:2375-90.

37. Zhang X, Zhang Z, Gu X, Mao S, Li X, Joël C, Alain P, Wang L, Zhang B. Genetic diversity of pepper (Capsicum spp.) germplasm resources in China reflects selection for cultivar types and spatial distribution. J Integr Agric 2016; 15(9): 1991-2001.

38. Ahn YK, Manivannan A, Karna S, Jun T-H, Yang E-Y, Choi S, Kim J-H, Kim D-S, Lee E-S. Whole genome resequencing of Capsicum baccatum and Capsicum annuum to discover single nucleotide polymorphism related to powdery mildew resistance. Sci Rep. 2018:8:5188.

39. Solomon AM, Han K, Lee J-H, Lee H-Y, Jang S, Kang B-C. Genetic diversity and population structure of Ethiopian Capsicum germplasms. PLOS ONE. 2019;14(5):e0216886 https://doi.org/10.1371/journal.pone.0216886.

40. Albrecht E, Zhang D, Mays AD, Saftner RA, Stomme JR. Genetic diversity in Capsicum baccatum is significantly influenced by its ecogeographical distribution. BMC Genet. 2012;13:68.

41. Moses M, Umaharan P. Genetic structure and phylogenetic relationships of Capsicum chinense. J Amer Soc Hort Sci. 2012;137(4):250-62.

42. Cardoso R, Ruas CF, Giacomin RM, Ruas PM, Ruas EA, Barbieri RL, Rodrigues $\mathrm{R}$, Goncalves LSA. Genetic variability in Brazilian Capsicum baccatum germplasm collection assessed by morphological fruit traits and AFLP markers. PLoS One. 2018;13(5):e0196468.

43. Mimura Y, Inoue T, Minamiyama Y, Kubo N. An SSR-based genetic map of pepper (Capsicum annum L. var. annuum) serves as an anchor for the alignment of major pepper maps. Breed Sci. 2012:62:93-8.

44. Xu Y, Ishii T, McCouch S, Mew T, Brar D, Peng S, Dawe D, Hardy B. Markerassisted evaluation of germplasm resources for plant breeding. In: Mew TW, Brar DS, Sun L, Cheng X, Wang S, Wang L, Liu C, Mei L, Peng S, Dawe D, Hardy B, editors. Rice Science: Innovations and Impact for Livelihood-Manila (IRRI); 2003. p. 213-29.

45. Zhang J, Xie W, Wang Y, Zhao X. Potential of start codon targeted (SCOT) markers to estimate genetic diversity and relationships among Chinese Elymus sibiricus. Molecules. 2015;20:5987-600.

46. Satya P, Karan M, Jana S, Mitra S, Sharma A, Karmakar PG, Ray DP. Start codon targeted (SCOT) polymorphism reveals genetic diversity in wild and domesticated populations of ramie (Boehmeria nivea L. Gaudich.), a premium textile fiber producing species. Meta Gene. 2015;3:62-70

47. Lamare A, Rao SR. Efficacy of RAPD, ISSR and DAMD markers in assessment of genetic variability and population structure of wild Musa acuminata colla. Physiol Mol Biol Plants. 2015;21(3):349-58. 
48. Pinar H, Bulut M, Altunoz D, Uzun A, Seday U, Yilmaz KU. Determination of genetic diversity and relationships within citrus and related genera using DAMD markers. Bangladesh J Bot. 2017;46(1):163-70.

49. Sawant SV, Singh PK, Gupta SK, Madnala R, Tuli R. Conserved nucleotide sequences in highly expressed genes in plants. J Genet. 1999;78:123-31.

50. Collard YP, Mackill DS. Molecular breeding and marker-assisted selection: International Service for the acquisition of Agro-Biotechnology Applications. Torino, Italy Torino publishing press Itd 2009; 43: 34-58.

51. Gorji AM, Poczai P, Polgar Z, Taller J. Efficiency of arbitrarily amplified dominant markers (SCOT, ISSR and RAPD) for diagnostic fingerprinting in tetraploid potato. American J Potato Res. 2011;88:226-37.

52. Murthy $\vee$. Population genetic analysis of common ragweed (Ambrosia artemisiifolia L.) in Europe using DNA-based molecular markers, MSc thesis. Keszthely: University of Pannonia; 2011.

53. Xiong F, Zhong R, Han Z, Jiang J, He L, Zhuang W, Tang R. Start codon targeted polymorphism for evaluation of functional genetic variation and relationships in cultivated peanut (Arachis hypogaea L.) genotypes. Mol Biol Report. 2011;38:3487-94.

54. Talebi R, Nosrati S, Etminan A, Naji AM. Genetic diversity and population structure analysis of landrace and improved safflower (Cartamus tinctorious L.) germplasm using arbitrary functional gene-based molecular markers. Biotechnol Biotec Eq. 2018;32:1183-94.

55. Heath DD, Iwana GK, Delvin RH. PCR primed with VNTR core sequences yield species specific patterns and hypervariable probes. Nucleic Acids Res. 1993;21:5782-5.

56. Jeffreys AJ, Wilson $V$, Thein SL. Hypervariable 'minisatellite' regions in human DNA. Nature. 1985;314:67-73.

57. Bilgen M, Karaca M, Onus AN, Ince AG. A software program combining sequence motif searches with keywords for finding repeats containing DNA sequences. Bioinformatics. 2004;20:3379-86.

58. Abarshi MM, Mohammed IU, Wasswa P, Hillocks RJ, Holta J, Legg JP, Seal SE, Maruthi MN. Optimization of diagnostic RT-PCR protocols and sampling procedures for the reliable and cost-effective detection of Cassava brown streak virus. J Virol Methods. 2010;163:353-9.

59. Seyedimoradi H, Talebi R. Detecting DNA polymorphism and genetic diversity in lentil (Lens culinaris Medik.) germplasm: comparison of ISSR and DAMD marker. Physiol Mol Biol Plants. 2014;20(4):495-500.

60. Jaccard P. Nouvelles recherches sur la distribution florale. Bull Soc Vaudoise Sci Nat. 1908:44:223-70.

61. Hamilton M. Population genetics. New York: Wiley-Blackwell; 2009. p. 234.

62. Talebi R, Fayaz R, Mardi M, Pirsyedi SM, Naji AM. Genetic relationships among chickpea (Cicer arietinum) elite lines based on RAPD and agronomic markers. Int J Agric Biol. 2008;8:301-5.

63. Saeed A, Hovsepyan H, Darvishzadeh R, Imtiaz M, Panguluri SK, Nazaryan R. Genetic diversity of Iranian accessions, improved lines of chickpea (Cicer arietinum L.) and their wild relatives by using simple sequence repeats. Plant Mol Biol Report. 2011;29:848-58.

64. Igwe DO, Afiukwa CA. Competency assessment of directed amplified minisatellite DNA and start codon targeted markers for genetic diversity study in accessions of Vigna subterranea (L.) Verdcourt. J Crop Sci Biotechnol. 2017;20(4):263-78.

65. Geleta LF, Labuschagne MT, Viljoen CD. Genetic variability in pepper (Capsicum annuum L.) estimated by morphological data and amplified fragment length polymorphism markers. Biodivers Conserv. 2005;14:2361-75.

66. Castañón-nájera G, Ramírez-Meraz M, Mayek-pérez N, Garcia AC, Ruíz-Salazar R. Molecular comparison of wild and commercial chilies from Tamaulipas and Tabasco. Mexico Pak J Bot. 2016;46(6):2101-6.

67. Souframanien J, Gopalakrishna T. A comparative analysis of genetic diversity in blackgram genotypes using RAPD and ISSR markers. Theor Appl Genet. 2004;109:1687-93.

68. Gajera BB, Kumar N, Singh AS, Punvar BS, Ravikiran R, Subhash N, Jadeja GC. Assessment of genetic diversity in castor (Ricinus communis L.) using RAPD and ISSR markers. Ind Crop Prod. 2010;32:491-8.

69. Que Y, Pan Y, Lu Y, Yang C, Yang Y, Huang NL. Genetic analysis of diversity within a Chinese local sugarcane germplasm based on start codon targeted polymorphism. BioMed Res Int. 2014;2014:1-10.

70. Cardoso MA, Provan J, Powell W, Ferreira PCG, De Oliveira DE. High genetic differentiation among remnant populations of the endangered Caesalpinia echinata Lam. (Leguminosaee-Caesalpinioideae). Mol Ecol. 1998;7:601e608.

71. Debajit S, Sukriti D, Sneha G, Mohan L, Singh BB. RAPD and ISSR based intra-specific molecular genetic diversity analysis of Cymbopogon flexuosus $L$.
Stapf with a distinct correlation of morpho-chemical observations. Res J Biotechnol. 2015;10:105-13.

72. Heikrujam M, Kumar J, Agrawal V. Genetic diversity analysis among male and female Jojoba genotypes employing gene targeted molecular markers, start codon targeted (SCOT) polymorphism and CAAT box-derived polymorphism (CBDP) markers. Meta Gene. 2015;5:90-7.

73. Botstein D, White RL, Skolnick M, Davis RW. Construction of a genetic linkage map in man using restriction fragment length polymorphisms. Am J Hum Genet. 1980;32:314-31.

74. Costa MR, Marques JRF, Silva CS, Veja Pla JL. Distâncias genética em equinos (Equus caballus) por meio de marcadores microssatélites. Revta Biociências. 2009;15:18-25.

75. Pandey MK, Gautami B, Jayakumar T, Sriswathi M, Upadhyaya HD, Gowda MVC, Radhakrishnan T, Bertioli D, Knapp SJ, Cook DR, Varshney RK. Highly informative genic and genomic SSR markers to facilitate molecular breeding in cultivated groundnut (Arachis hypogaea). Plant Breed. 2012;131:139-47.

76. Seyedimoradi H, Talebi R, Hassani D, Karami F. Comparative genetic diversity analysis in Iranian local grapevine cultivars using ISSR and DAMD molecular markers. Environ Exp Biol. 2012;10:125-32.

77. Pakseresht F, Talebi R, Karami E. Comparative assessment of ISSR, DAMD and SCOT markers for evaluation of genetic diversity and conservation of landrace chickpea (Cicer arietinum L.) genotypes collected from north-west of Iran. Physiol Mol Biol Plants. 2012;19(4):563-74.

78. Nei M. Estimation of average heterozygosity and genetic distance from a small number of individuals. Genet. 1978;89:583-90.

79. Karron JD. Patterns of genetic variation and breeding systems in rare plant species. In: Falk D, Holsinger K, editors. Genetics and conservation of rare plants. New York: Oxford University Press; 1991. p. 87-98pp.

80. Hernández VS, González AR, Sánchez PP, Casas A, Oyama K. Estructura y diferenciación genética de poblaciones silvestres y domesticadas de chile del Noreste de México analizada con Isoenzimas y RAPDs. Rev Fitotec Mex. 2006;29(2):25-9.

81. Harish A, Gupta K, Phulwaria M, Rai MK, Shekhawat NS. Conservation genetics of endangered medicinal plant Commiphora wightii in Indian Thar Desert. Gene. 2014;535:266-72.

82. Li J, Jin Z. Genetic variation and differentiation in Torreya jackii Chun, an endangered plant endemic to China. Plant Sci. 2007;172:1048-53.

83. Ranjbarfard A, Saleh G, Ashikin N, Abdullah P, Kashiani P. Genetic diversity of lemba (Curculigo latifolia) populations in peninsular Malaysia using ISSR molecular markers. Australia J Crop Sci. 2014;8(1):9-17.

84. Kumar A, Mishra P, Singh SC, Sundaresan V. Efficiency of ISSR and RAPD markers in genetic divergence analysis and conservation management of Justicia adhatoda L., a medicinal plant. Plant Syst Evol. 2014;300:1409-20.

85. Twyford AD, Kidner CK, Harrison N, Ennos RA. Population history and seed dispersal in widespread central American Begonia species (Begoniaceae) inferred from plastome-derived microsatellite markers. Botan J Linnean Soc. 2013;171:260-76.

86. Wright S. The genetic structure of populations. Ann Eugenics. 1951;15:313-54.

87. Slatkin M, Barton NH. A comparison of three indirect methods for estimating average levels of gene flow. Evolution. 1989:43:1349-68.

88. Bacchetta G, Fenu G, Mattana E. Genetic variability of the narrow endemic Rhamnus persicifolia Moris (Rhamnaceae) and its implications for conservation. Biochem Sys Ecol. 2011;39:477-84.

89. Li K, Chen L, Feng Y. High genetic diversity but limited gene flow among remnant and fragmented natural populations of Liriodendron chinense Sarg. Biochem Sys Ecol. 2014;54:230-6.

\section{Publisher's Note}

Springer Nature remains neutral with regard to jurisdictional claims in published maps and institutional affiliations. 